\title{
Impact of Incentives on Perfromance of Sports Administrators and Athletes in Anambra State Sports Council
}

\author{
Dr. Deemua G.A.*, Uzoegbo Ifeoma V. \\ Department of Human Kinetics and Health Education University of Port Harcourt \\ *Corresponding Author: Dr. Deemua G.A., Department of Human Kinetics and Health Education \\ University of Port Harcourt
}

\begin{abstract}
This study investigated the impact of incentives on performance of sports administrators and athletes in Anambra state sports council. A sample of 289sports administrators and athletes were used for the study. The instrument for data collection was tagged, 'Perceived Impact of Incentives on Performance of Sports Administrators and Athletes'. The reliability coefficient of the instrument was established using testretest method and Pearson product moment correlation technique was 0.86. The analysis of the data generated was done with the use of meanwhile hypotheses were analysed using z-test. The results of the study showed that majority of the respondents perceived incentives as positive indicator to motivate high performance and competence which were significant at probability level of 0.05. From the hypotheses analysed, the result indicated that there is no significant difference on perceived effects of incentives by sports administrators and athletes. Based on the findings, it was recommended that government and private organisations should create an avenue for effective incentives scheme and monitor properly.
\end{abstract}

Keywords: Incentives, Performance, Administrators, Athletes

\section{INTRODUCTION}

Sports and human existence cannot be separated because involvement in competition have been part and parcel of human existence. Orunaboka and Ammah (2004) stated that sports is as old as man, in which from the ancient time up to the present generation, people have been participating in sporting activities either directly or indirectly in an orderly manner as friends and brothers. Participation in sports generally, all over the world has taken a new dimension and those who are involved in it have different motives, as sports has grown from a mere recreational exercise to a scientific activity. The development of science and technology created new opportunities which totally changed people way of thinking.

For certain contributions to human being as a result of sports participation, Deemua (2019) defined sports participation or involvement in sporting activity as an active or experienced that gives enjoyment, fun and relaxation which requires vigorous bodily exertion and is guided by some traditional set of rules whether outdoor or indoor. Participation in sports is also believed to depend to a large extent on various biological, psychological and cultural antecedents. In the same vein, Emerbe and Achara (2003) people participate in sports especially competitive sports for mere beneficial consequences such as enhancing upward social mobility, healthy lifestyle, development of special skills and competencies, promoting happiness and self-actualization, tolerance and cooperation, good physical condition, free from coronary diseases. They further stated that male and female athletes gain success, professionalism and interventional recognition.

Learning basic movement skills is the first step toward learning sports-specific skills for athletic performance. According to Dessler (2008) training provides employees to enhance their ability in order to perform at their jobs and can build a good reputation of the management team. Training is described as the learning process which is able to temporary change employee ability for the efficiency and effectiveness on job performance (Decenzo\& Robbins, 2000).

People relate to sports through participation ranging from the occasional weekend participation (amateur) and daily training for payment of professional athletes. An athlete is a person who competes in one or more sports that involve physical strength, speed or endurance. Most athletes train and 
compete either full time or part-time depending on their schedule and at times they depend on sports for their livelihood. The amateur athlete are all persons who are directly and regularly involved in a formal competition governed by an official sports body but who received no external rewards (other than trophies, plagues, unificates, scholarship etc.) those who play on a high school team, compete regularly in a sanctioned road races, compete in a golf league (Skedentop, 2001). These people have regular commitments in their sports participation and compete under conditions governed by sportsorganisations, where rules are enforced, records are typically kept, and seasonal champions are determined while professional athletes are all persons who competes for immediate profit or who sign contracts to compete for remuneration or for a team or within a sportsorganisaton. They include those who play in NBA, in many professional soccer leagues throughout the world, on the ladies Professional Golf Association tour or in the national water-ski etc. (Siedentop, 2001). Although, amateur and professional athletes have a few things in common, such as swine shared skills and passion for their sports; the primary difference lies in the fact that for professionals, performance within a sports can make or break their careers.

Besides, in the administration of sports, there is the need to guide, motivate, control the efforts of people who are sports inclined. A sports administrator is that individual who demonstrates his expertise or characteristics within the context of the sports organization to accomplish its purpose(s). When athletes have been discovered, the sports administrator must plan and carryout programmes to transform them into outstanding sportsmen and women. It is this administrative approach that Ikulayo (1993) as cited in Onohwakpor (2008) described as building confidence framework that instills selfconfidence, self-esteem, enthusiasm and motivation in the athletes to cope with training and competition demands.

In essence, the effects of incentives on performance of sports administrators and athletes have long been of interest, for quite some time now in the context of this study, incentives is something that motivates an individual to perform an action. The level and amount of effort in a person will either increase or decrease on the basis of the quality of incentives offered to the person (Kundu\&Tutoo, 2002).

In line with this view, Eboh (1992) noted that incentives, are essential gadgets or the totality of the factors which should assist sportsmen and women to whichever their goals. In the same vein, Orlick (1981), incentives motivates, energies and spurs one to action and at the same time, it is capable of sustaining high performance level, because it is contained in the process of obtaining one's optimum goals. It is necessary that when athletes and sports administrators have been provided with sufficient incentives in a supportive and attractive environment, they will behave, learn new skills and achieve level of performance towards the goal setting of the sports council.

However, incentives, both monetary and non-monetary may have invariably influenced the performance behaviours of athletes and sports administrators. Obviously, not all incentives are created equal and the rewards that you find motivating might not be enough to inspire another person to take action. The fundamental purpose of incentive is to provide positive consequences for contributions to desired performance (Wilson, 2013). Monetary rewards are used to motivate human behaviours in a number of ways. In the athletic context, players are often enticed to improve their performance to obtain higher salaries, bonuses or tournament rewards. Monetary incentives are used by employers to attract, retain as well as compensate best work force for a job well done (Milton, 2013). Non-financial incentives are listed as enabling authority, participating in the management, job enrichment, promotion, holidays, better working atmosphere and enhancing sense of belonging (Erabsi\&Anat, 2012). Conversely, in sports setting and athletic competitions, praise, recognition and a stimulating environment are non-financial rewards that can motivate high performance and creativity.

\section{Statement of The Problem}

In the history of Nigerian sports, incentives have been undermined and this tendency has filtered through sports participation and athletes performance. The issue of incentives in sports participation have become a growing concern among sports administrators, athletes and sportsorganisations.

Ikwunze (2006), pointed out that during the ancient Olympics, winners of sports events were reward with flowers of Olive leaves from the sacred grave of Zeus, had their status erected and were 
exempted from paying tax forever as a reward with monetary, but lately, winners of sports events have been rewarded with monetary rewards, medals, certificates, scholarship, job offer and promotion to ensure they maintain their standard in subsequent competitions.

Incentives are given to sports officials and athletes as an appreciation for their sacrifices and contributions in the field of sports. Hence, the purpose of this study emitted as a result of low performance in sports in Anambra State and may be sequel to the poor application of incentives. Based on the above perspectives, the researcher tends to find out the effect of incentives on athletes performance.

\section{AIM AND OBJECTIVES OF THE STUDY}

The aim of the study is to find out the perceived effects of incentives on performance of sports administrators and athletes in Anambra state Sports Council. Specifically, the study seeks to:

1) To determine the incentives available to enhance performance of sports administrators and athletes in Anambra State Sports Council

2) To ascertain the most preferred incentive to enhance performance of sports administrators and athletes in Anambra State Sports Council.

3) To determine the perceived effects of incentives on performance of sports administrators and athletes in Anambra State Sports Council

\subsection{Research Questions}

The following research questions were formulated to guide the study:

1. What are the incentives available to enhance performance of sports administrators and athletes in Anambra State Sports Council?

2. What is the most preferred incentive to enhance the performance of sports administrators and athletes in Anambra State Sports Council?

3. What is the perceived effect of incentives on performance of sports administrators and athletes by sports administrators and athletes in Anambra State Sports Council?

\subsection{Hypotheses}

The following null hypotheses were tested at an alpha level of 0.05 .

1. There is no significant difference on the incentives available for sports administrators and athletes in Anambra State Sports Council.

2. There is no significant difference on the preferred incentive for performance by sports council

3. There is no significant difference in the perceived effects of incentives on performance by sports administrators and athletes in Anambra State Sports Council?

\section{Methodology}

The study adopted a cross-sectional survey design. The population of the study comprise three hundred and sixty-one (361) sports administrators and athletes attached to Anambra State Sports Council. The entire population was used out of which 289 were properly filled and were finally used as the sample size. The instrument used was a self-structural questionnaire tagged: "PELOPSAA" based on the research questions. The face and content validity was done by experts. Using the test retest method, the reliability calculated using Pearson's product moment correlation yielded an index of 0.86. Mean and standard deviation were used to answer the research questions, while z-test was employed to test the hypotheses at 0.05 alpha level.

\section{RESUlts}

The following research questions were formulated to guide the study;

\section{Research Question 1}

What are the incentives available to enhance performance of sports administrators and athletes in Anambra State Sports Council? 
Impact of Incentives on Perfromance of Sports Administrators and Athletes in Anambra State Sports Council

Table1. Mean $(\bar{x})$ and Standard Deviation (SD) of the incentives available for sports administrators and athletes Anambra State Sports Council $(n=289)$

\begin{tabular}{|c|c|c|c|c|c|c|}
\hline \multirow{3}{*}{$\begin{array}{l}\mathbf{S} / \mathbf{N} \\
1 . \\
\end{array}$} & \multirow{3}{*}{$\begin{array}{l}\text { Items } \\
\text { Scholarship award }\end{array}$} & \multirow{2}{*}{\multicolumn{2}{|c|}{$\begin{array}{l}\text { Sports } \begin{array}{l}\text { Administrators }(n=48) \\
\bar{x}\end{array} \quad \text { SD }\end{array}$}} & \multirow{2}{*}{\multicolumn{2}{|c|}{$\begin{array}{l}\text { Athletes }(\mathrm{n}=\mathbf{2 4 1}) \\
\overline{\mathrm{x}} \quad \text { SD }\end{array}$}} & \multirow{3}{*}{$\begin{array}{l}\text { Remark } \\
\text { Available } \\
\end{array}$} \\
\hline & & & & & & \\
\hline & & 3.25 & 1.63 & 3.05 & 1.51 & \\
\hline 2. & Medal & 3.53 & 1.76 & 3.16 & 1.58 & Available \\
\hline 3 & Cars & 2.13 & 1.07 & 2.01 & 1.01 & Not Available \\
\hline 4 & Land & 1.90 & 0.95 & 1.70 & 0.85 & Not Available \\
\hline 5. & Allowances & 2.88 & 1.44 & 2.53 & 1.23 & Available \\
\hline 6. & Financial Reward & 2.83 & 1.42 & 2.58 & 1.29 & Available \\
\hline 7. & Sports Equipment & 3.54 & 1.77 & 3.15 & 1.58 & Available \\
\hline 8. & $\begin{array}{l}\text { Admission into } \\
\text { Educational Institution }\end{array}$ & 2.99 & 1.50 & 2.96 & 1.48 & Available \\
\hline 9. & Free Medical Care & 2.98 & 1.49 & 2.71 & 1.36 & Available \\
\hline 10 & Job Offer & 2.92 & 1.46 & 2.85 & 1.43 & Available \\
\hline
\end{tabular}

Table 1 above revealed that scholarship award (sports administrators $\overline{\mathrm{x}}=3.25, \mathrm{SD}=1.63$; Athletes $\overline{\mathrm{x}}$ $3.16, \mathrm{SD}=1.58$ ), sports equipment (sports administrators $\overline{\mathrm{x}} 3.54, \mathrm{SD}=1.77$, Athletes $\overline{\mathrm{x}} 3.15, \mathrm{SD}=$ 1.29 are most available for sports administrators and athletes. However, Allowance (sports administrators $\overline{\mathrm{x}} 2.88, \mathrm{SD}=1.44$, athletes $\overline{\mathrm{x}} 2.53, \mathrm{SD}=1.23$ ), financial reward (sports administrators $\overline{\mathrm{x}}$ 2.83, $\mathrm{SD}=1.42$, Athletes $\overline{\mathrm{x}} 2.58, \mathrm{SD}=1.291$, Administrators $\overline{\mathrm{x}}=2.98, \mathrm{SD}=1.49$, Athletes $\overline{\mathrm{x}}=2.71$, $\mathrm{SD}=1.36$ ), and Job offer (sports administrators $\overline{\mathrm{x}}=2.92, \mathrm{SD}=1.46$, Athletes $\overline{\mathrm{x}}=2.85$, Athletes $\overline{\mathrm{x}}=$ $2.85, \mathrm{SD}=1.43$ ) are also available for sports administrators and Athletes while cars (sports administrators $\overline{\mathrm{x}} 2.13, \mathrm{SD}=1.07$, Athletes $\overline{\mathrm{x}}=2.01, \mathrm{SD}=1.01$ ) and Land (sports administrators $\overline{\mathrm{x}}=$ $1.90, \mathrm{SD}=0.95$, Athletes $\overline{\mathrm{x}}=1.70, \mathrm{SD}=0.85$ ) were never available to sports administrators and athletes in Anambra State Sports Council.

\section{Research Question 2}

What are the most preferred incentives to enhance the performance of sports administrators and athletes in Anambra State Sports Council?

Table2. Mean $(\bar{x})$ and Standard Deviation $(S D)$ of the most preferred incentive by sports administrators and athletes in Anambra State Sports Council $(n=289)$

\begin{tabular}{|c|c|c|c|c|c|c|c|}
\hline $\mathbf{S} / \mathbf{N}$ & Items & $\begin{array}{l}\text { Sport } \\
(\mathbf{n}= \\
\overline{\mathbf{x}}\end{array}$ & & Remark & $\begin{array}{l}\text { Athl } \\
(\mathbf{n}= \\
\overline{\mathbf{x}} \\
\end{array}$ & $\begin{array}{l}\text { es } \\
\text { S1) } \\
\text { SD }\end{array}$ & Remark \\
\hline 1. & Scholarship award & 3.17 & 1.59 & $4^{\text {th }}$ & 2.92 & 1.46 & $5^{\text {th }}$ \\
\hline 2. & Medal care & 3.19 & 1.60 & $3^{\text {rd }}$ & 3.04 & 1.52 & $2^{\text {nd }}$ \\
\hline 3 & Medals & 2.97 & 1.49 & $7^{\text {th }}$ & 2.73 & 1.42 & $9^{\text {th }}$ \\
\hline 4 & Financial reward & 3.65 & 1.83 & $1^{\mathrm{st}}$ & 3.48 & 1.74 & $1^{\mathrm{st}}$ \\
\hline 5. & Cars & 2.69 & 1.35 & $10^{\text {th }}$ & 2.84 & 1.27 & $7^{\text {th }}$ \\
\hline 6. & Land & 3.15 & 1.59 & $6^{\text {th }}$ & 2.90 & 1.45 & $6^{\text {th }}$ \\
\hline 7. & Allowances & 3.16 & 1.58 & $5^{\text {th }}$ & 3.10 & 1.51 & $4^{\text {th }}$ \\
\hline 8. & Sports equipment & 2.78 & 1.39 & $9^{\text {th }}$ & 2.62 & 1.31 & $10^{\text {th }}$ \\
\hline 9. & Job offer & 3.28 & 1.64 & $2^{\text {nd }}$ & 3.03 & 1.52 & $3^{\text {rd }}$ \\
\hline 10 & $\begin{array}{l}\text { Admission into } \\
\text { educational institution }\end{array}$ & 2.97 & 1.49 & $7^{\text {th }}$ & 2.82 & 1.42 & $8^{\text {th }}$ \\
\hline
\end{tabular}

Table 2 shows that financial reward (sports administrators $\overline{\mathrm{x}}=3.65$, SD $=1.83$, Athletes $\overline{\mathrm{x}}=3.48$, SD $=1.74$ ) was the most preferred incentives by the respondents, the second incentives was Job offer (sports administrators $\overline{\mathrm{x}}=3.28, \mathrm{SD}=1.64$ ) and Free medical (athletes $\overline{\mathrm{x}}=3.04, \mathrm{SD}=1.52$ ) Free medical was third incentive preferred by sports administrators $(\overline{\mathrm{x}}=3.19$, SD $=1.60)$ while Job offer (athletes $\overline{\mathrm{x}}=3.03, \mathrm{Sd}=1.52$ ) was the third preferred by the athletes, the fourth incentive preferred by the respondent was scholarship (sports administrators $\overline{\mathrm{x}}=3.17, \mathrm{SD}=1.59$ and Allowances (athletes $\overline{\mathrm{x}}$ 3.01, SD 1.51), the fifth preferred by sports administrators was allowances $(\overline{\mathrm{x}}=3.16, \mathrm{SD}=1.58)$ while the fifth preferred by the athletes was scholarship award $(\overline{\mathrm{x}}=2.92, \mathrm{SD}=1.46)$, and the sixth preferred was land (sports administrators $\overline{\mathrm{x}}=3.15, \mathrm{SD}=1.1 .59$, athletes $\overline{\mathrm{x}}=2.90, \mathrm{SD}=1.45$ ). In the 
table above, there is a tie between medals $(\overline{\mathrm{x}}=2.97, \mathrm{SD}=1.49$ and Admission into educational institution $(\overline{\mathrm{x}}=2.97, \mathrm{SD}=1.49)$ of seventh and eight preference of sports administrators while athletes preferred cars $(\overline{\mathrm{x}}=2.84, \mathrm{SD}=1.27)$ as seventh preference and admission into educational institution $(\overline{\mathrm{x}}=2.82, \mathrm{SD}=1.40)$ as the eight preference. The least preferred incentives by sports administrators was sports equipment $(\overline{\mathrm{x}}=2.78, \mathrm{SD}=1.39)$ and cars $(\overline{\mathrm{x}}=2.69, \mathrm{SD}=1.35)$ while athletes least preferred was medals $(\overline{\mathrm{x}}=2.73, \mathrm{SD}=1.42)$ and sports equipment $(\overline{\mathrm{x}}=2.62, \mathrm{SD}=1.31)$ respectively.

\section{Research Question 3}

What is the perceived effect of incentive on performance by sports administrators and athlete in Anambra State Sports Council?

Table3. Mean $(\bar{x})$ and Standard Deviation (SD) of the perceived effect of incentives by sports administrators and athletes Anambra State Sports Council $(n=289)$

\begin{tabular}{|l|l|l|l|l|l|l|}
\hline S/N & Items SD & \multicolumn{2}{|l|}{$\begin{array}{l}\text { Sports Administrators } \\
(\mathbf{n = 4 8} \text { SD } \\
\overline{\mathbf{x}}\end{array}$} & \multicolumn{2}{|l|}{$\begin{array}{l}\text { Athletes } \\
\mathbf{( n = 2 4 1})\end{array}$} & Remark \\
\hline 1. & $\begin{array}{l}\text { Sports administrators and athletes } \\
\text { perform better when officially } \\
\text { recognized by government and } \\
\text { offering team reward }\end{array}$ & 3.60 & 1.63 & 3.25 & 1.47 & Effect \\
\hline 2. & $\begin{array}{l}\text { Non-monetary reward of cars, } \\
\text { medals, etc. increase motivation and } \\
\text { enhance performance }\end{array}$ & 3.29 & 1.44 & 2.94 & 1.39 & Effect \\
\hline 3 & $\begin{array}{l}\text { Social recognition and } \\
\text { acknowledgement of task well-done } \\
\text { retain high performance }\end{array}$ & 3.34 & 1.11 & 2.99 & 0.99 & Effect \\
\hline 4 & $\begin{array}{l}\text { Financial incentive is a positive } \\
\text { motivational influence that improves } \\
\text { performance of sports administrators } \\
\text { and athletes }\end{array}$ & 3.67 & 1.81 & 3.32 & 1.56 & Effect \\
\hline 5. & $\begin{array}{l}\text { Training allowances build a strong, } \\
\text { engaged and high performance team }\end{array}$ & 3.45 & 1.57 & 3.10 & 1.41 & Effect \\
\hline
\end{tabular}

It is evident in the table 3 above that the respondents perceived financial incentive is a positive motivational influence that improves performance (Sports administrator $\overline{\mathrm{x}}=3.67$ ), $\mathrm{SD}=1.81$, Athletes $\overline{\mathrm{x}}=3.32, \mathrm{SD}=1.56$ ), Sports administrators and athletes perform better when officially recognized by government and offering team reward (Sports administrators $\bar{x}=3.60, S D=1.63$, Athletes $\overline{\mathrm{x}}=3.25, \mathrm{SD}=1.47$ ), Training allowances build a strong, engaged and high performing team (Sports administrators $\overline{\mathrm{x}}=3.45, \mathrm{SD}=1.57$, Athletes $\overline{\mathrm{x}}=3.10, \mathrm{SD}=1.41$ ), social recognition and acknowledgement of task well-done retain high performance (Sports administrators $\overline{\mathrm{x}}=3.34, \mathrm{SD}=$ 1.11, Athletes $\overline{\mathrm{x}}=2.99, \mathrm{SD}=0.99)$ and Non-monetary reward of cars, medals, etc. increase motivation and enhance performance (Sports administrator $\overline{\mathrm{x}}=3.29, \mathrm{Sd}=1.44$, Athletes $\overline{\mathrm{x}}=2.94, \mathrm{SD}$ $=1.39$ ) as a positive effect that enhances performance as the mean values are greater than criterion mean $(\overline{\mathrm{x}}))$ of 2.50 .

\section{Hypotheses 1}

There is no significant difference on the incentives available for sports administrators and athletes in Anambra State Sports Council.

Table4. Summary of z-test of no significant difference on the incentives available for sports administrators and athletes in Anambra State Sports Council

\begin{tabular}{|l|l|c|l|l|l|l|l|l|}
\hline Rank & $\mathbf{N}$ & $\overline{\mathrm{X}}$ & SD & z-cal & z-crt & Df & Alpha Level & Decision \\
\cline { 1 - 5 } Sports administrators & 48 & 3.53 & 1.24 & \multirow{2}{*}{1.60} & \multirow{2}{*}{1.960} & 287 & 0.05 & \multirow{2}{*}{$\mathrm{H}_{0}$ Accepted } \\
\cline { 1 - 5 } & & & & & & & & \\
\hline
\end{tabular}

Table 4 above shows that the calculated z-value (1.60) is less than the critical z-value (1.90) at degree of freedom of 287 and 0.05 level of significance. Therefore, the null hypothesis was accepted. Hence, 
there is no significance difference on the incentives available for sports administrators and athletes in Anambra State Sports Council.

\section{Hypotheses 2}

There is no significant difference on the preference of incentives on performance by sports administrators and athletes in Anambra State Sports Council.

Table5. Summary of z-test of no significant difference on the preference of incentives on performance by sports administrators and athletes in Anambra State Sports Council

\begin{tabular}{|l|l|c|l|l|l|l|l|l|}
\hline Rank & $\mathbf{N}$ & $\overline{\mathbf{x}}$ & SD & z-cal & z-crt & Df & Alpha Level & Decision \\
\cline { 1 - 5 } Sports administrators & 48 & 3.86 & 1.92 & \multirow{2}{*}{1.97} & \multirow{2}{*}{1.960} & 287 & 0.05 & $\mathrm{H}_{0}$ Rejected \\
\cline { 1 - 5 } & & & & & & & & \\
\hline Athletes & 241 & 3.32 & 1.23 & & & & & \\
\hline
\end{tabular}

Table 5 above shows that z-critical value (1.960) is less than the z-cal (1.97) with degree of freedom of 287 and 0.05 level of significance. Hence, the null hypothesis was rejected. Therefore, there is significance in preference of incentive on performance by sports administrators and athletes in Anambra State Sports Council.

\section{Hypotheses 3}

There is no significant difference on the perceived effects of incentives on performance by sports administrators and athletes in Anambra State Sports Council.

Table6. Summary of z-test of no significant difference on the perceived effect of incentives on performance by sports administrators and athletes in Anambra State Sports Council

\begin{tabular}{|l|l|c|l|l|l|l|l|l|}
\hline Rank & $\mathbf{N}$ & $\overline{\mathrm{x}}$ & SD & z-cal & z-crt & Df & Alpha Level & Decision \\
\hline $\begin{array}{l}\text { Sports } \\
\text { administrators }\end{array}$ & 48 & 3.41 & 1.27 & \multirow{2}{*}{1.63} & 1.960 & 287 & 0.05 & $\mathrm{H}_{0}$ Accepted \\
\cline { 1 - 6 } Athletes & 241 & 3.10 & 1.04 & & & & & \\
\hline
\end{tabular}

From the table above, the null hypothesis $\left(\mathrm{H}_{0}\right)$ is accepted since at 0.05 alpha level and DF (287), the calculated $\mathrm{z}$-value (1.63) is less than the critical $\mathrm{z}$-value (1.960). Hence, there is no significant difference on the perceived effects of incentives on performance by sports administrators and athletes in Anambra State Sports Council.

\subsection{Discussion of Findings}

The findings of this study are hereby discussed according to the research questions and hypotheses.

The findings in table 1 shows a summary table of mean and standard deviation of the incentives available for sports administrators and athletes. According to the findings, it can be said that sports equipment was most available incentive for sports administrators while medals was most available for athletes. Then cars and land were never available for both sports administrators and athletes. The findings are suppressing and is in disagreement with the findings of Tshube, Akpata and Irwin (2012) that scholarship awards have been available for a long period of time and still remain the most available incentives in the sporting arena.

The findings in table 2shows that financial reward ranked highest which is the most preferred followed by job offer, medical care, scholarship award, allowances, land ,admission into educational institution, metals, sports equipment and the least rank was cars. The findings are not surprising and this is in disagreement with Senchi, (2000), his findings showed that scholarship awards ranked highest, followed by employment opportunities, monetary award and the least ranked was allowance. This study shows that there are incentives that are more attractive than others hence they can be ranked in the order of preference. It is evident that incentives are diverse and respondents preferences are equally diverse.

The findings in table 3 also shows mean and standard deviations of perceived effect of incentives on performance. The findings revealed that respondents perceived financial incentive as a positive motivational influence that improves performance. The findings from this study challenge those from other reinvestigation who reported negative effects of monetary incentives (Agrawal, 2012; Ariely et 
al.; 2009 \& Mobbs et al.; 2009) conducted a research on the effects of monetary incentives on athletic performance. Also, non-monetary reward of cars, medals etc. increase motivation and enhance performance was perceived by respondent as a positive effect on performance. This findings is in agreement with Tshube, Akpata, and Irwin (2012) that studied the use of non-monetary incentives as a motivational tool in sports. The results suggest that non-monetary incentives is a useful supplement to monetary incentives in motivating athletes to win medals, particularly in Africa where economics are struggling.

In table 4 shows the summary of z-test of no significant difference on the incentives available for sports administrators and athletes. The calculated $\mathrm{z}$-value (1.60) is less than the critical $\mathrm{z}$-value (1.960) at 0.05 alpha level, hence the null hypotheses was accepted.

The findings in table 5 shows that the null hypothesis was rejected since at 0.05 level of significant with degree of freedom of 287 , the z-calculated (1.97) is greater than the z-critical value (1.960). Hence, there is significant difference in preference of incentives on performance by sports administrators.

Table 5 indicates that there is no significant difference on the perceived effects of incentives on performance by sports administrators and athletes since the z-calculated is less than z-critical at 0.05 alpha level of and 287 degree of freedom. Therefore, the null hypothesis is accepted.

The findings in table 6 indicate that the z-calculated value (1.37) is less than z-critical value (1.960) at 0.05 level of significant. IN essence, the null hypothesis is accepted.

\section{CONCLUSION}

The outcome of this study showed that there are differences in incentive preference among respondents. It is imperative that incentives be administered with caution since not all of them elicit the same motivational response as intended. It should be noted that if sports administrators and athletes need incentive to perform, lack of such incentives can lead to decrease in motivation. In other words, use of incentives as a motivational tools was perceived as a positive indicator to competence. Both financial and non-financial incentives play important role in motivating sports men and women in pursuit of excellence in sports.

\section{Recommendations}

From the findings of the study, the following recommendations were made;

1. The government should create an avenue for effective incentive scheme and monitor properly.

2. Sports council should ensure that reward schemes reflect competence, skill and high performance

3. There should be a system that will ensure that funds are readily available to sports industry

4. To management should articulate and authenticate a welfare package so as to meet up with organizational goals.

5. Sound incentive package should be based on a strategy that is systematic, flexible and adaptable

6. National athletes who meet certain criteria should be given grants to train for international competitions

7. Sponsors should be encouraged to come into sports by given them tax rebates.

8. The government, in consultation with sporting organizations, athlete representatives and other stake holders, should formulate policy guidelines for sports performance incentives at various levels of sports performance in Anambra State

\section{REFERENCES}

[1] Decenzo, D.A. \& Robbins S.P. (2000).Facilitating optimal motivation and psychological well-being across life's domains.Canadian Psychology, 49, 14-23.

[2] Deemua, G.A. (2019). Risk factors and management of sportss injuries among secondary school athletes in Khana local government area, Rivers State.Journal of African contemporary Research, 10(1), 157-162

[3] Dessler, G. (2008). Human Recourse Management (11 ${ }^{\text {th }}$ edition). New Jersey: Pearson Education

[4] Erbasi, A. (2012). The effect of financial and non-financial incentives on job satisfaction; An examination of Food Chain Premises in Turkey. International Business Research, 5(10). 
[5] Kandu, C.L/ \&Tutoo, D.N. (2002). Educational Psychology. New Delhi India: Sterling Publishers PVT Ltd.

[6] Milton, (2013).The role of monetary and non-monetary incentives in the workplace. As influence by career stage: Institute of Food and Agricultural Sciences. University of Florida Gainesvills.

[7] Onohwakpor, A.E.O. (008). Organisation of sports programmes. In F.O. Money, (Ed) Essential of Sports Science and Health Education, Benin: Bonpeco Publishers

[8] Orunaboka, T.T. \&Ammah, AJ.O. (2004). Indiscipline in the society. The role of physical education and sports. Nigerian Journal of empirical Studies in Psychological and education, Port Harcourt, 1(9), $197-$ 184.

[9] Siedentop, D. (2001). Introduction to physical education, fitness and sports ( $4^{\text {th }}$ ed). London: Mayfield publishing company

[10] Wilson, B.T. (2013). Innovative reward systems for the changing work place. New York: McGraw Hill.

Citation: Dr. Deemua G.A., Uzoegbo Ifeoma V. "Impact of Incentives on Perfromance of Sports Administrators and Athletes in Anambra State Sports Council" International Journal of Sports and Physical Education (IJSPE), vol 6, no. 2, 2020, pp. 27-34. doi: https://doi.org/10.20431/2454-6380.0602004.

Copyright: () 2020 Authors. This is an open-access article distributed under the terms of the Creative Commons Attribution License, which permits unrestricted use, distribution, and reproduction in any medium, provided the original author and source are credited. 